\title{
Environmental Risk for the Freshwater Ecosystem of the Yenisei River with Consequences for Human Health Risks
}

\author{
Serhii Lydia Bondareva*1, Natalya Fedorova ${ }^{1}$, Hasrat Arjjumend ${ }^{2,3}$ \\ ${ }^{1}$ Federal Scientific Center for the Hygiene named after F.F. Erisman, Mitischi, Moscow Region, Russia \\ ${ }^{2}$ Université de Montréal Faculté de Droit, Maximilien-Caron Pavilion, C. P. 6128, Downtown, Montreal, \\ Québec, H3C 3J7, Canada \\ ${ }^{3}$ Centre for International Sustainable Development Law, McGill University Faculty of Law, Montreal \\ (Quebec) H3A 1X1, Canada \\ *Corresponding author (E-mail: lydiabondareva@gmail.com)
}

\begin{abstract}
How to cite this paper: Bondareva, S.L., Fedorova, N. and Arjjumend, H. (2018). Environmental Risk for the Freshwater Ecosystem of the Yenisei River with Consequences for Human Health Risks. Grassroots Journal of Natural Resources, 1(2): 22-34. Doi:

https://doi.org/10.33002/nr2581.6853.01023
\end{abstract}

Received: 12 October 2018

Reviewed: 22 November 2018

Provisionally Accepted: 25 November 2018

Revised: 03 December 2018

Finally Accepted: 10 December 2018

Published: 31 December 2018

Copyright () 2018 by author(s) and

The Grassroots Institute.

This work is licensed under the Creative Commons Attribution International License (CC BY 4.0).

http://creativecommons.org/licenses/by/4.0/
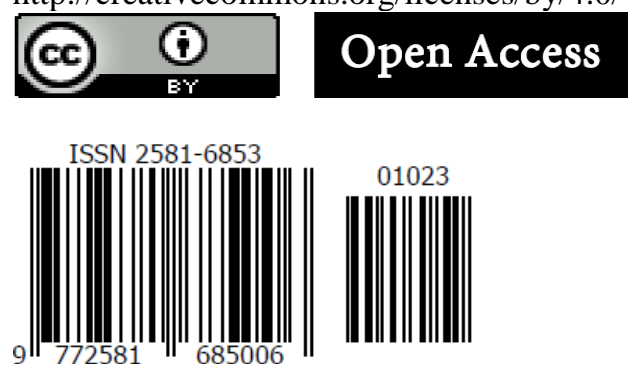

\begin{abstract}
The long-term monitoring of the state of the freshwater ecosystem of the River Yenisei revealed the statistically reliable content of heavy metals ( $\mathrm{Fe}, \mathrm{Zn}, \mathrm{Cd}, \mathrm{Cu}, \mathrm{U}$, etc.) in the water, bottom sediments, phyto- and zoo-plankton, and muscle mass of commercial fish (benthos eaters, predators and herbivorous fish) consuming different types of food. The values of the indices of the ecological state of the Yenisei River were estimated to vary from 2.38 to 2.85 . The total index of risk for the water, considering the reference doses, amounts to 0.16 for the water, and to 0.47 for the flesh of commercial fish. The total index of risk for the population consuming freshwater and fish from the Yenisei River amounts to $I R=0.63$. The obtained value of the index is, in general, of no danger for the population health. Though the carcinogenic substances were not accurately revealed, non-carcinogenic substances were estimated to the level of non-threshold risks. The non-threshold risks of noncarcinogenic substances was found 0.017, far lower than permissible limit 0.050 . The ratio of reflectory-olfactory effects and total non-carcinogenic risk was found, respectively, 0.01 and 0.34 . The integrated indictor was 0.35 , which did not exceed the regulatory level $(\mathrm{II} \leq 1)$. Conclusively, the risks associated to various analyzed indicators did not exceed the permissible levels and did not require additional measures of monitoring the water quality.
\end{abstract}

\section{Keywords}

Environmental risk; Yenisei River; reference dose; carcinogenic substances 


\section{Introduction}

The human is constantly influenced by a great number of environmental factors, which can negatively influence his health and increase the risk of diseases (Baird, Rubach and Van den Brink, 2008; Bogardi et al., 1996; GAO, 2001). Risk, in its general meaning, is understood to be a calculated or estimated probability of an undesirable threat from any actions of a person, a group of people, an organization, or a State, etc. In the system of socio-hygienic monitoring, one considers the risk (potential danger) for the health of a particular person, a group of people, a part of population or for the population as a whole that appears or is expected to appear from adverse effect of particular environmental factors.

To substantiate the main parameters optimizing the functioning of the socio-hygienic monitoring, it is essential to understand 'technogenic toxicants', which are marker chemical substances and diagnostic test-systems for bio-monitoring and environmental diagnostics. They are used to validate the regional permissible levels of toxicants and microelements in an organism, and the levels of functional and clinical laboratory indicators of the state of organs and systems (Zemlyanova, 2002; Potapov and Yastrebov, 2000; Jardine et al., 2003; Malkhazova and Koroleva, 2011; Ives and Carpenter, 2007; Stepanova, 2008). World over, the water is considered a scarce resource. Both the qualities as well as quantity of water are declining seriously. However, the attitude of society to water is inappropriate considering water as inexhaustible natural resource. It has resulted in the aggravation of the socio-ecological problem of water supply (Vykhristyuk, 1989; Onischenko, Zaitseva and May, 2014; Dmitriev, 2014).

The population in Krasnoyarsk region of Russian Federation is affected by adverse environmental factors. The Krasnoyarsk region has a great economic potential including the freshwater supply - the River Yenisei. The main components of river's freshwater ecosystem were studied in particular contexts of their interpenetration, interconnection, interdependence, and interaction. Thus, assessing the ecological-hygienic risks for the human environment, addressing complex monitoring research on the freshwater ecosystem of the Yenisei River and revealing the trophic connections and regularities between the different components, needs primary importance from the viewpoint of the impacts of environmental risks on living organisms including human being.

\section{Methods and Materials}

\section{Description of the area under study}

The study area, Krasnoyarsk region, consist of the population of 2875.3 thousand people as on January 2017. At three different sites of sampling, the number of inhabitants living in the settlements included as under:

Site № $1-1153.5$ thousand people $(\sim 40 \%)$;

Site № $2-254.9$ thousand people $(\sim 9 \%)$;

Site № $3-32.3$ thousand people $(\sim 1 \%)$.

In most of the towns and settlements of the Krasnoyarsk region, there is a centralized system of water supply with the water withdrawal from in-channel and infiltration water intake facilities.

\section{Sampling and Methods}


The sampling of water, bottom sediments, fish, phytoplankton and zoobenthos is described as under:

Water: Water samples were taken in 2-L plastic bottles from the upper layer of the river flow (0$10 \mathrm{~cm})$ at a distance of 40-60 m from the shoreline. All water samples were taken at a distance of $500 \mathrm{~m}$ from the right bank in the main navigable channel with the highest flow velocity and depth larger than $5 \mathrm{~m}$. The sampling parameters were developed in accordance of sampling methods performed previously (Bondareva, Fedorova and Rakitskii, 2017; Bondareva and Schultz, 2015). Within a very short time (no more than 8-10 hours) after sampling, all the samples were filtered to remove suspended particles and placed in airtight glass containers following the recommendations given in the relevant literature (Moore and Ramamurthy, 1987).

Bottom sediments: Sampling of the surface layer $(10 \mathrm{~cm})$ of the bottom sediments was carried out using a Petersen grab in the corresponding vertical cross sections (right bank, channel, left bank). The sampling, fixation and storing of the bottom sediment was carried out in accordance with the requirements given in the international manuals on sampling and analyzing bottom sediments (Deckere et al., 2000). The sediment core samples were fully filled with water; and the vessels were closed during transportation, so as to minimize the possible water motion and mechanical disturbances (Deckere et al., 2000). The bulk density was measured immediately after the samples were delivered to the laboratory. The bottom sediments were stored overnight in a chamber with controlled atmosphere, maintaining the temperature close to that of the water flow $\left(\sim 5^{\circ} \mathrm{C}\right)$. After that, the samples in the naturally moist state were passed through a sieve with a mesh size of 500 $\mu \mathrm{m}$. The sample moisture content was determined using a separate weighed portion by drying at $105^{\circ} \mathrm{C}$ to constant weight. The reproducibility in the determination of the moisture content of the bottom sediment samples varied within the limits of uncertainty of the gravimetric analysis method, being within 3\%. The statistical data on the moisture content were obtained from five replicate portions of each bottom sediment sample with a confidence level of 0.95 .

Zoobenthos: All the samples were collected with a standard Ekman dredge. The zoobenthos samples were sieved through a $200 \mu \mathrm{m}$ sieve. The zoobenthos sampling sites corresponded to the sampling sites for the bottom sediments and aquatic plants. After the sampling, the zoobenthos was thoroughly washed and immediately frozen in portable freezers for the subsequent laboratory investigations. A total of 40 species belonging to three groups of organisms were found in the zooplankton community, namely: Cladocera (19 species), Copepoda (5 species), and Rotatoria (16 species) groups. The tritium content was determined for each of the three groups separately.

Phytoplankton: Phytoplankton samples were taken according to the recommendations given in the paper by Majaneva and OSPAR (Majaneva et al., 2009; OSPAR, 2016) using a water sampler BM-48 with the volume of 1.51 of water at a depth of $0.5 \mathrm{~m}$ from the water surface in the photic water layer. Photic layer is surface layer of the river that receives sunlight. The total number and biomass of species were estimated. The alga flora consisted of diatoms, cyanobacteria, Pyrrhophyta and Euglenophyta. The average number of phytoplankton in water samples was about $9.82 \pm 2.19$ million cells per litre.

Fish: When sampling the ichthyologic material and its laboratory processing the recommendations of Portt et al. (2006), EPA 100-B-00-001 (2000) and Murphy and Willis (1996) were used. In the fish harvest, the number and species composition were determined. The 
number of fish was estimated using the method of direct enumeration. The species composition was determined using some recommendations as given by Pravdin (1966) and Lukyanenko (1983). The accumulation of toxicants in aquatic organisms was estimated using the coefficient of biological absorption $\left(\mathrm{K}_{\mathrm{BA}}\right)$ which was calculated as a ratio of the toxicant content in the aquatic organism (fish, phytoplankton, zoobenthos) to the toxicant content in the environment (water, bottom sediments). The collected samples of aquatic organisms were dried at a temperature not higher than $80^{\circ} \mathrm{C}$ (to decrease the loss of highly volatile elements) (Portt et al., 2006; EPA 100-B-00-001, 2000; Murphy and Willis, 1996; Lukyanenko, 1983). After homogenization of an average sample, parts having mass of $0.5 \mathrm{~g}$ were decomposed in a microwave oven of Anton Paar GmbH make (Perkin-Elmer) in a mixture of purified concentrated nitric acid and sulphuric acid at a temperature of $230-250^{\circ} \mathrm{C}$ (Portt et al., 2006; EPA 100-B-00001, 2000; Murphy and Willis, 1996; Lukyanenko, 1983). The elements in all the liquids were determined by the method of mass spectrometry with inductively coupled plasma (ICP MS) on a quadrupole mass spectrometer Agilent 7500a (Agilent Technologies, USA). The samples were diluted 125 times with a solution of $\mathrm{HNO}_{3}(0.3 \mathrm{wt} . \%)$ in deionized water.

\section{Results}

Using the techniques as described in methodology above, the samples were analyzed to know the contents of number of elements (metals, non-metals, including radionuclides) (Table1).

Table 1. The content of some elements in water in different areas of the River Yenisei. Sampling in 2009-2016.

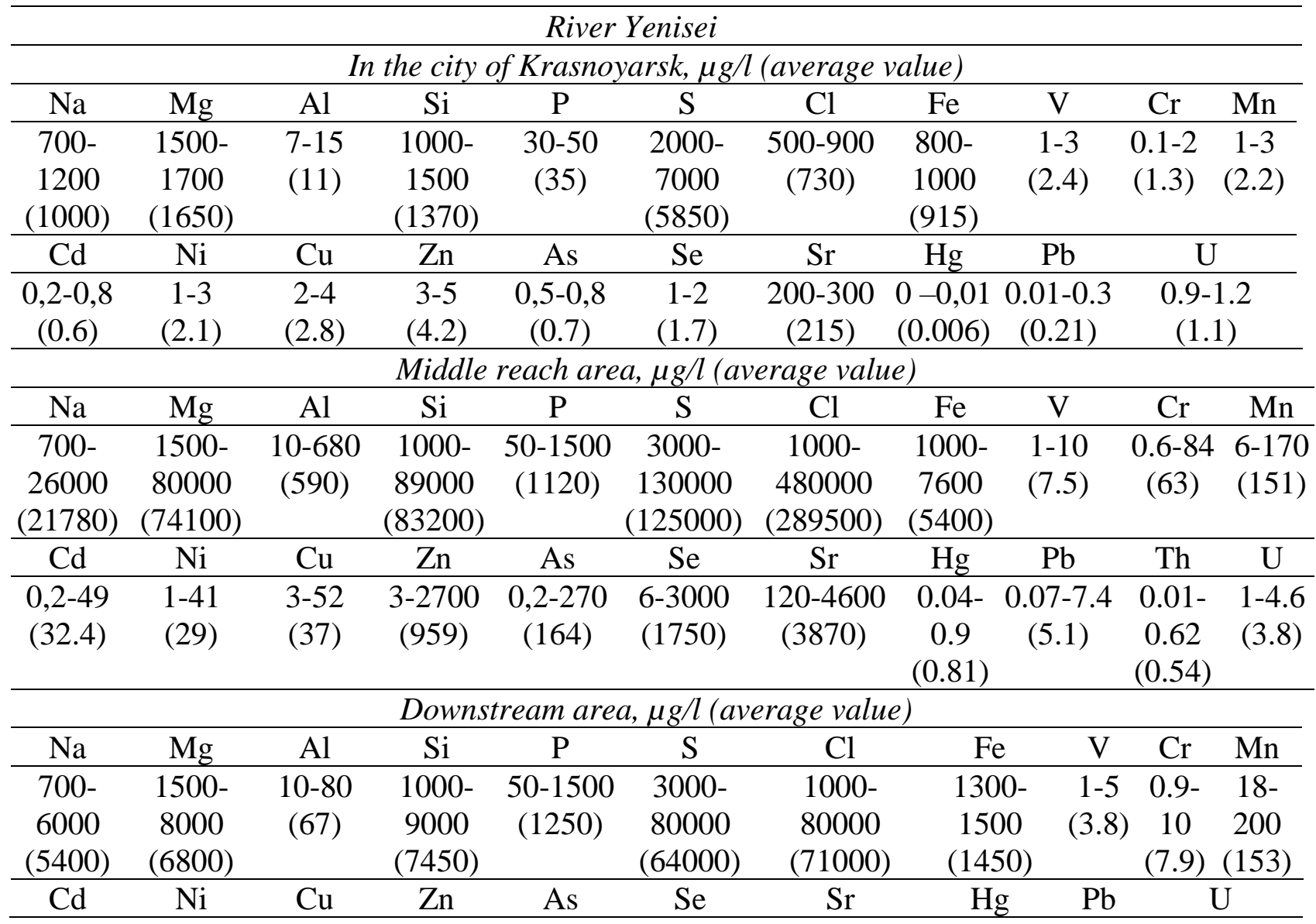




\begin{tabular}{llllllcccc}
$0.2-4$ & $1-11$ & $3-32$ & $3-700$ & $0.2-7$ & $2-30$ & $120-600$ & $0.04-0.6$ & $0.1-$ & $1.2-3.9$ \\
$(3.2)$ & $(9.7)$ & $(28)$ & $(638)$ & $(5,3)$ & $(17)$ & $(480)$ & $(0.54)$ & 3.7 & $(2.4)$ \\
& & & & & & & & $(2.5)$ \\
\hline
\end{tabular}

Table 2 presents the results of determining the content of heavy metals which was revealed in the muscle tissues of all the fish samples under study. Similarly, table 3 presents the coefficients of the biological toxicant accumulation $\left(\mathrm{T}_{\mathrm{BA}}\right)$ in the fish.

Table 2. The content of some heavy metals in the muscle mass of commercial fish in the River Yenisei. Sampling in 2009-2016.

\begin{tabular}{ccccccc}
\hline \multirow{2}{*}{ Metal } & \multicolumn{7}{c}{ Content of heavy metals, $\mathrm{mg} / \mathrm{kg}$} \\
\cline { 2 - 7 } & \multicolumn{2}{c}{ Herbivorous $(n=35)$} & \multicolumn{2}{c}{ Predators $(n=16)$} & \multicolumn{2}{c}{ Benthos eaters $(n=24)$} \\
\cline { 2 - 7 } $\mathrm{Zn}$ & $1.40-3.40$ & $2.36 \pm 0.10$ & $1.5-6.1$ & $2.811 \pm 0.097$ & $1.2-18.9$ & $4.23 \pm 0.11$ \\
\hline $\mathrm{Cd}$ & $0.005-0.034$ & $0.008 \pm 0.001$ & $0.003-0.080$ & $0.009 \pm 0.001$ & $0.005-0.050$ & $0.008 \pm 0.004$ \\
\hline $\mathrm{Cu}$ & $0.11-0.50$ & $0.212 \pm 0.016$ & $0.300-0.590$ & $0.439 \pm 0.007$ & $0.110-0.550$ & $0.291 \pm 0.006$ \\
\hline $\mathrm{Fe}$ & $2.1-6.5$ & $2.85 \pm 0.17$ & $1.70-8.40$ & $3.25 \pm 0.14$ & $1.8-24.0$ & $4.97 \pm 0.22$ \\
\hline $\mathrm{U}$ & $0.02-0.15$ & $0.040 \pm 0.006$ & $0.02-0.22$ & $0.068 \pm 0.007$ & $0.02-5.20$ & $0.089 \pm 0.026$ \\
\hline $\mathrm{Mn}$ & $0.11-0.31$ & $0.218 \pm 0.008$ & $0.08-0.41$ & $0.237 \pm 0.008$ & $0.090-0.900$ & $0.27 \pm 0.01$ \\
\hline $\mathrm{Pb}$ & $0.02-0.54$ & $0.057 \pm 0.018$ & $0.004-0.780$ & $0.105 \pm 0.105$ & $0.020-1.800$ & $0.098 \pm 0.012$ \\
\hline
\end{tabular}

As far as the accumulation in all the tissues and organs is concerned, Fe occupies the first position. It is not surprising considering a great role of iron in the respiratory and hematopoietic systems. Iron is necessary for metabolism of an organism. It takes part in the porphyrite synthesis in hemoglobin and myoglobine. $\mathrm{Zn}$ is also a vital element that is the constituent of many enzymes. $\mathrm{Cu}$, referred to a group of microelements, plays an important role in the organism as a catalyst of redox processes (Ivanov, 1994; Bondareva and Zhizhaev, 2010; Bondareva, 2010; Bondareva et al., 2013).

The data on the average content of the elements in the muscle mass of the fish is found in the agreement with biochemical role of the metals in the life activity of an organism. Data in table 4 represents the contents and toxicant accumulation coefficients of some metals in the phytoplankton, zoobenthos and bottom sediments of the River Yenisei.

Table 3. The coefficients of biological accumulation $\left(K_{B A}\right)$ of the main toxicants in the fish muscle mass depending on the toxicant content in the water of the studied area.

\begin{tabular}{cccccccccc}
\hline & \multicolumn{9}{c}{ Accumulation coefficient, l/mg } \\
\cline { 2 - 10 } & \multicolumn{3}{c}{ Herbivorous } & \multicolumn{3}{c}{ Predators } & \multicolumn{3}{c}{ Benthos eaters } \\
\cline { 2 - 10 } & \multicolumn{3}{c}{ Site } & \multicolumn{3}{c}{ Site } & \multicolumn{3}{c}{ Site } \\
\cline { 2 - 10 } & №1 & №2 & oo3 & №1 & №2 & №3 & №1 & №2 & №3 \\
\hline $\mathrm{Zn}$ & $590 \pm 12$ & $2.5 \pm 0.5$ & $3.7 \pm 0.8$ & $669 \pm 20$ & $2.9 \pm 0.8$ & $4.4 \pm 1.1$ & $1058 \pm 53$ & $4.41 \pm 1.13$ & $6.63 \pm 2.01$ \\
\hline $\mathrm{Cd}$ & $13.3 \pm 2.3$ & $0.03 \pm 0.01$ & $2.5 \pm 0.7$ & $15 \pm 2$ & $0.03 \pm 0.01$ & $2.8 \pm 0.9$ & $13.3 \pm 2.1$ & $0.02 \pm 0.01$ & $2.5 \pm 1.1$ \\
\hline $\mathrm{Cu}$ & $55.8 \pm 7.2$ & $5.73 \pm 1.3$ & $7.6 \pm 1.3$ & $113 \pm 10$ & $11.9 \pm 2.5$ & $15.7 \pm 2.1$ & $76.6 \pm 12$ & $7.87 \pm 2.01$ & $10.4 \pm 3.1$ \\
\hline $\mathrm{Fe}$ & $3.11 \pm 0.85$ & $0.53 \pm 0.12$ & $2.0 \pm 0.8$ & $3.6 \pm 0.8$ & $0.62 \pm 0.17$ & $2.24 \pm 0.8$ & $5.46 \pm 3.02$ & $0.92 \pm 0.24$ & $3.43 \pm 1.72$ \\
\hline $\mathrm{U}$ & $40 \pm 12$ & $10.5 \pm 1.4$ & $17 \pm 2$ & $62 \pm 3$ & $17.9 \pm 4.1$ & $28.3 \pm 3.8$ & $80.9 \pm 5.7$ & $23.4 \pm 6.1$ & $37.1 \pm 4.2$ \\
\hline $\mathrm{Mn}$ & $99.1 \pm 3.4$ & $1.44 \pm 0.12$ & $1.4 \pm 0.6$ & $108 \pm 8$ & $1.57 \pm 0.62$ & $1.6 \pm 0.6$ & $123 \pm 17$ & $1.79 \pm 0.65$ & $1.76 \pm 0.41$ \\
\hline $\mathrm{Pb}$ & $271 \pm 10$ & $11.2 \pm 2.1$ & $23 \pm 3$ & $500 \pm 21$ & $20.6 \pm 7.2$ & $42 \pm 7$ & $467 \pm 24$ & $19.2 \pm 5.8$ & $39.2 \pm 10.5$ \\
\hline
\end{tabular}

Serhii Lydia Bondareva, Natalya Fedorova, Hasrat Arjjumend 
Table 4. The averaged characteristics of the metal content in the bottom sediments (range), phytoplankton, zoobenthos of the River Yenisei and coefficients of biological accumulation ( $\left.K_{B A}\right)$. Sampling in 2009-2016.

\begin{tabular}{cccccc}
\hline Indicator & \multicolumn{5}{c}{ Average content, $\mathrm{mg} / \mathrm{kg}$ (range) } \\
\cline { 2 - 6 } & $\mathrm{Zn}$ & $\mathrm{Cu}$ & $\mathrm{Pb}$ & $\mathrm{Ni}$ & $\mathrm{Cr}$ \\
\hline Bottom sediments & $18.0 \pm 2.4$ & $3.3 \pm 0.5$ & $2.0 \pm 1.0$ & $14.5 \pm 2.4$ & $4.5 \pm 0.7$ \\
& $(5-43)$ & $(1-7)$ & $(0,5-5,0)$ & $(3-21)$ & $(0.7-10)$ \\
\hline Phytoplankton & $100.5 \pm 34.5$ & $26.4 \pm 6.5$ & $2.4 \pm 0.9$ & $5.1 \pm 1.3$ & $14.3 \pm 5.6$ \\
\hline $\mathrm{K}_{\mathrm{BA}}, \mathrm{mg} / \mathrm{mg}$ & $5.58 \pm 1.21$ & $8 \pm 2$ & $1.2 \pm 0.85$ & $0.35 \pm 0.11$ & $3.18 \pm 1.27$ \\
\hline Zoobenthos & $22.9 \pm 16.2$ & $11.4 \pm 1.8$ & $4.2 \pm 1.0$ & $5.3 \pm 2.3$ & $5.7 \pm 2.1$ \\
\hline $\mathrm{K}_{\mathrm{BA}}, \mathrm{mg} / \mathrm{mg}$ & $1.27 \pm 0.65$ & $3.46 \pm 1.13$ & $2.1 \pm 1.3$ & $0.37 \pm 0.11$ & $1.27 \pm 0.43$ \\
\hline
\end{tabular}

The metals under study belong to a group of cationogenic water migrants which, depending on the ability to migrate in water and its bioaccumulation in the most widespread natural conditions, can be arranged into the following sequence: $\mathrm{Zn} \geq \mathrm{Cu} \geq \mathrm{Pb} \geq \mathrm{Ni} \geq \mathrm{Cr}$.

\section{Discussion}

The complex assessment of the ecological state (status) of the river Yenisei was based on the method of expert evaluation of the ecosystem quality, which is the simplest approach to reveal the ecological issues in the water ecosystems through detecting in the ecosystem the presence or absence of certain indicating organisms sensitive to complex and specific pollution. This method also uses the evidence on the quantity and biomass of the indicating organism groups and on the dynamical characteristics of the population (Baird, Rubach and Van den Brink, 2008; GAO, 2001; Potapov and Yastrebov, 2000; Onischenko, Zaitseva and May, 2014; Moore and Ramamurthy, 1987).

To choose the main chemical substances the major criteria were the following: the level of their content in the water, number of consumers subjected to their impact, high resistance and ability to be accumulated in trophic chains. Based on the performed studies the priority factors of ecological and hygiene risks for sustainable functioning of the freshwater ecosystem of the River Yenisei were established (Table 5). At the stage of the exposure evaluation the impact scenario was determined by including type of the pollution source, impact route, duration of the exposure, frequency of the exposure, and number of the exposed population. Carcinogenic substances were not detected in the studied water samples, thus the characterization of risks concerning the substances without carcinogenic effect was made by comparing the actual daily impact (daily dose) with the reference dose (Shakirova, 2006; Rivier and Bakanov, 1984; Onishchenko, 2003).

Table 5. The priority factors of ecological and hygiene risks for sustainable functioning of the freshwater ecosystem of the River Yenisei

\begin{tabular}{cc}
$\begin{array}{c}\text { Objects of the } \\
\text { risk analysis }\end{array}$ & \multicolumn{1}{c}{$\begin{array}{c}\text { Abiotic: } \text { water } \\
\text { Biotic: fish }\end{array}$} \\
\hline Factors of risk & $\begin{array}{l}\text { Stable inorganic substances of natural and anthropogenic origin: toxic ions } \\
\text { of heavy metals }(\mathrm{Cu}, \mathrm{Zn}, \mathrm{Ni}, \mathrm{Cd}, \mathrm{Pb} \text { etc. }) \text {, radionuclides with different } \\
\text { half-life periods and mechanisms of interaction with living organisms. }\end{array}$ \\
\hline
\end{tabular}




\begin{tabular}{ll}
\hline Main threats & $\begin{array}{l}\text { Risk of pollution of the water environment } \\
\text { Risk of the accumulation of metals and radionuclides in fish } \\
\text { Risk for the population health when using the water and contaminated fish }\end{array}$ \\
\hline $\begin{array}{l}\text { Criteria of the } \\
\text { risk assessment }\end{array}$ & $\begin{array}{l}\text { Indices characterizing the ecological state of the system. } \\
\text { Dose loading for biological objects. }\end{array}$ \\
\hline
\end{tabular}

Assessment of ecological risks for the human habitat

As the main quantitative indicators for the assessment of ecological risks, the following indices were used:

1. Sub-index characterizing the water quality (IWQ)

$$
I W Q=\frac{\sum_{i=1}^{n} H_{i}}{N_{h}},
$$

where $H_{i}$ and $N_{h}$ are the relative estimates on a scale from 1 to 4 for the hydro-chemical indicators and ingredients used (Stepanova, 2008).

2. Sub-index of the biotic state of phytoplankton and zooplankton $\left(I B S_{p h}\right)$, which is calculated based on the evidence obtained during the present studies as well

$$
I B S_{p h}==\frac{\sum_{i=1}^{n} B_{i}}{N_{b}},
$$

where $B_{i}$ is the relative estimate of the used biological indicators on a scale from 1 to 4 , and $N_{b}$ is the number of the biological indicators analyzed.

3. The sub-index $I B S_{b}$ characterizes the state of bottom sediments which is determined by the ternary method (Stepanova, 2008).

4. Sub-index $I B S_{f}$ (indicator of the biological state of fish) characterizes the pathologoanatomical state of fish (Stepanova, 2008).

5. Sub-index $I P H$ characterizes the state of the population health being estimated by the exceeded average level of incidence of environmentally-dependent diseases (the calculations were based on the data provided in the governmental reports of the Krasnoyarsk Region. 2014-2016).

To estimate the integrated value of the index of ecological state (IES) of a water reservoir, it is suggested that the indicated quantitative parameters should be taken into account. Each of the sub-indices is being assigned a definite statistical weight $\left(k_{i}\right)$.

$$
I E S=\frac{\sum\left(I B S_{p h+I B S_{f}}+I P H+I B S b+I W Q+I B S z\right)}{6}
$$

The ecological potential and risk for the ecosystem of the Yenisei River was estimated through the IES value (Table 6). In assessing the ecological state of the River Yenisei, indicators were assigned the weight coefficient, depending on the regional conditions. The obtained IES values (Table 6), among others, included the integrated indicator of the state of the river mouth of some right-bank tributaries of the Yenisei.

Table 6. The data used in estimating IES of the River Yenisei for the areas under study and several right-bank tributaries

\begin{tabular}{lccccccc}
\hline $\begin{array}{l}\text { The source } \\
\text { under study }\end{array}$ & $\mathrm{IBS}_{\mathrm{ph}}$ & $\mathrm{IBS}_{\mathrm{z}}$ & $\mathrm{IBS}_{\mathrm{f}}$ & $\mathrm{IBS}_{\mathrm{b}}$ & $\mathrm{IPH}$ & IWQ & IES \\
\hline $\begin{array}{l}\text { Weight } \\
\text { coefficient }\end{array}$ & 1 & 1 & 1 & 1 & 2 & 2 & n.d. \\
\hline
\end{tabular}




\begin{tabular}{|c|c|c|c|c|c|c|c|}
\hline $\begin{array}{l}\text { Yenisei River, } \\
\text { site } 1\end{array}$ & 3 & 3 & 2.6 & 2,8 & 1 & 4.5 & 2.82 \\
\hline $\begin{array}{l}\text { Yenisei River, } \\
\text { site } 2\end{array}$ & 3.2 & 3 & 2.5 & 3 & 1 & 4.5 & 2.38 \\
\hline $\begin{array}{l}\text { Yenisei River, } \\
\text { site } 3\end{array}$ & 3 & 3 & 2.5 & 3.1 & 1 & 4.5 & 2.85 \\
\hline
\end{tabular}

*n.d.- no data.

The data given in the Table 6 shows that all the studied transacts of the river Yenisei possess a high ecological potential with a moderate level of ecological risk. The sub-index characterizing the ecological state of the area in terms of the population health (IPH) does not significantly contribute to the generalized index IES.

\section{Assessment of hygienic and cumulative (integrated) risks}

The assessment of risks for the population health potentially connected with the potable water consumption was performed in accordance with the chemical risk assessment, 2001 (GAO, 2001). RfD is the reference dose from the database of the integrated information system on risks and tables of assessment of the health effect (IRIS/HEAST). The evaluation of the exposure for the conditions of perioral intake, with the standard values recommended by WHO (2004) was used, which resulted in the following: the water consumption $-21 /$ day; frequency of the impact 365 days; duration of the impact - 70 years; body weight $-70 \mathrm{~kg}$; averaging period, number of days - 365 days during 70 years. The maximum daily exposure was taken to be 24 hours. The exposure was calculated using the formula:

$$
C C D_{i}=\frac{C_{i} \cdot V_{i} \cdot t}{T \cdot M}
$$

$\mathrm{Ci}$ is the concentration of the chemical substance in the water, $\mathrm{mg} / \mathrm{l}$

$V i$ is the volume of the carrier-substance being in contact with the human organism, 1

$t$ is the contact duration, years

$T$ is the duration of the averaged period, years

$M$ is the body weight, $\mathrm{kg}$

At the stage of the exposure estimation for the conditions of the peroral intake of the identified compounds with the water the average daily doses were calculated (Table 7).

Table 7. The values of the anticipated average daily doses (I) of the substances contained in the water of the river Yenisei at site № 1, belonging to the territory of the Krasnoyarsk city with the population of more than 1 million people, $\mathrm{mg} /(\mathrm{kg} *$ day $)$

\begin{tabular}{|c|c|c|c|c|c|}
\hline № & Indicator & $\begin{array}{c}\text { Concentration } \\
\text { of the substance, } \\
m g / l\end{array}$ & $R f D$ & $\begin{array}{c}A D D \\
\text { (average daily } \\
\text { dose, } \mathrm{mg} / \mathrm{kg} * \text { day) }\end{array}$ & $\begin{array}{l}\text { Number of the } \\
\text { exposed } \\
\text { population } \\
\text { thousand people }\end{array}$ \\
\hline 1 & Hydrocarbonate & 13.8 & * & 4.79 & 1153.5 \\
\hline 2 & $\mathrm{Cu}$ & 0.004 & 0.019 & $1.14 \cdot 10^{-4}$ & 1153.5 \\
\hline 3 & $\mathrm{Mn}$ & 0.003 & 0.14 & $8.75 \cdot 10^{-5}$ & 1153.5 \\
\hline 4 & $\mathrm{Cr}$ & 0.0013 & 0.005 & $3.71 \cdot 10^{-5}$ & 1153.5 \\
\hline 5 & $\mathrm{Zn}$ & 0.005 & 0.3 & $1.43 \cdot 10^{-4}$ & 1153.5 \\
\hline 6 & $\mathrm{~V}$ & 0.0024 & 0.007 & $3.46 \cdot 10^{-5}$ & 1153.5 \\
\hline
\end{tabular}




\begin{tabular}{cccccc}
\hline 7 & $\mathrm{Hg}$ & 0.00001 & 0.0003 & $2.85 \cdot 10^{-7}$ & 1153.5 \\
\hline 8 & $\mathrm{~Pb}$ & 0.0003 & 0.0035 & $8.57 \cdot 10^{-6}$ & 1153.5 \\
\hline 9 & $\begin{array}{c}\text { Compounds (U- } \\
\text { solvable in water) }\end{array}$ & 0.0011 & 0.0006 & $3.14 \cdot 10^{-5}$ & 1153,5 \\
\hline 10 & $\mathrm{Ni}$ & 0.0021 & 0.02 & $6 \cdot 10^{-4}$ & 1153.5 \\
\hline 11 & Dry residue & 84.5 & $-^{*}$ & 2.315 & 1153.5 \\
\hline
\end{tabular}

${ }^{*}$ Reference doses were not established.

** data as of 1 January 2017.

The value of the total index of risk for the water was calculated:

$$
\begin{gathered}
\Sigma И P_{\theta}=\frac{C C D_{C u}}{R f D_{C u}}+\frac{C C D_{M n}}{R f D_{M n}}+\frac{C C D_{C r}}{R f D_{C r}}+\frac{C C D_{Z n}}{R f D_{Z n}}+\frac{C C D_{V}}{R f D_{V}}+\frac{C C D_{H g}}{R f D_{H g}}+\frac{C C D_{P b}}{R f D_{P b}}+\frac{C C D_{U}}{R f D_{U}}+\frac{C C D_{N i}}{R f D_{N i}}= \\
=0.1585
\end{gathered}
$$

The obtained value of the index of risk is significantly lower than 1 , which evidences the permissible content of the studied pollutants in the water from the source of potable water supply.

To analyze the total index of risk of pollutants incoming with fish, results given in table 2 were used. In the calculation of the average daily dose, concentrations $\left(C_{i}\right)$ of the chemicals in the medium (fish) were used. $V_{i}$ is the volume of the carrier of the chemical substance being in contact with the human organism during a day in accordance with the EPA standards (EPA/630/R-00/001, 2000), a single daily intake of fish amounting to $113 \mathrm{~g}$ ). The risk was estimated for the conditions of the life-long (70 years) consumption of food by a person weighing $70 \mathrm{~kg}$.

$$
\begin{aligned}
& \Sigma И P_{p}=\frac{C C D(Z n)}{R f D(Z n)}+\frac{C C D(C d)}{R f D(C d)}+\frac{C C D(C u)}{R f D(C u)}+\frac{C C D(F e)}{R f D(F e)}+\frac{C C D(U)}{R f D(U)}+\frac{C C D(M n)}{R f D(M n)}+\frac{C C D(P b)}{R f D(P b)}= \\
& =0.47
\end{aligned}
$$

The obtained value of the index of risk shows that the consumption in muscles of fish with the established content of metals is safe for the population. The total index of risk (IR) for the population living at site № 1 ( $\sim 40 \%$ of the population of the entire region) and consuming water and fish from the river Yenisei amounts to $\sim 0.63$. The obtained value (value $<1$ ) of risk is of no danger for the health of population.

In the risk assessment, the values of the reference doses of the studied substances (12 substances) or the values of the maximum allowable concentrations (MAC) (7 compounds) were analyzed. At the stage of the risk assessment for reflectory-olfactory effects, characteristics of the main organoleptic indicators of the water quality and those of the forming substances (Table 8) were obtained.

Table 8. The risk assessment for the reflectory-olfactory effects in the potable water

\begin{tabular}{ccccc}
\hline Criterion analyzed & Value & MAC, $\mathrm{mg} / \mathrm{ml}$ & Prob $^{*}$ & Risk \\
\hline Smell & 0 & 2 & & 0 \\
\hline Savour at $20^{0} \mathrm{C}$ & 0 & 2 & & 0 \\
\hline Color & 0 & 20 & -3.33 & 0 \\
\hline muddiness & 0 & 1.5 & -3 & 0 \\
\hline Hydrogen indicator & 7.5 & 9 & -3.1 & 0.001 \\
\hline Total hardness & 2.6 & 7 & -3.222 & 0.007 \\
\hline
\end{tabular}




\begin{tabular}{ccccc}
\hline Chlorides & 1.41 & 350 & -3.09812 & 0 \\
\hline Dry residue & 78 & 500 & -3.1364 & 0.001 \\
\hline Residual chloride, unbound & 0.08 & 0.5 & -4.6423 & 0 \\
\hline Residual chloride, bound & 0.06 & 1.2 & -6.3119 & 0 \\
\hline Total risk for the the reflectory-olfactory effects & & 0.001 \\
\hline Allowable value of the reflectory-olfactory effects & & 0.1 \\
\hline
\end{tabular}

*Here, the value Prob is an intermediate value to pass from the concentration of the adverse substance to the health risk.

The total estimate of the organoleptic risk from using the given potable water was equal to 0.001 , with the priority factors being the dry residue and hydrogen indicator. The results of the assessment of the non-carcinogenic risk for the potable water are given in table 9.

Table 9. The values of the non-threshold non-carcinogenic risk for the substances in the potable water

\begin{tabular}{cccc}
\hline Indicator & MAC & $\begin{array}{c}\text { Concentration of } \\
\text { substances, } \mathrm{mg} / l\end{array}$ & Risk \\
\hline Sulfates & 500 & 6.05 & 0.0005 \\
\hline Chlorides & 350 & 6.00 & 0.0008 \\
\hline Dry residue & 1000 & 38.75 & 0.0014 \\
\hline $\begin{array}{c}\text { Residual Chloride, } \\
\text { unbound }\end{array}$ & 0.5 & 0.08 & 0.0028 \\
\hline $\begin{array}{c}\text { Residual Chloride, } \\
\text { bound }\end{array}$ & 1.2 & 0.06 & 0.0117 \\
\hline Allowable risk of chronical intoxication & $\leq 0.02$ \\
\hline Total non-threshold non-carcinogenic risk & 0.0172 \\
\hline Allowable value of non-threshold non-carcinogenic risk & $\leq 0.05$ \\
\hline
\end{tabular}

As is seen in the table, the non-threshold non-carcinogenic risks for the particular substances under consideration did not exceed the allowable level of 0.05 and was equal to 0.017 . Understanding the characteristics of the risk is the final stage of the risk assessment, the integrated assessment of risk (summation of the effects) was performed to measure the quality of the potable water supplied to the distributed network (Table 10).

Table 10. The estimation of the integrated indicator for the potable water

\begin{tabular}{cccc}
\hline Type of risk & $\begin{array}{c}\text { Value of the total } \\
\text { estimate }\end{array}$ & $\begin{array}{c}\text { Value of the } \\
\text { allowable quantity }\end{array}$ & $\begin{array}{c}\text { Ratio of risk to the } \\
\text { allowable value }\end{array}$ \\
\hline $\begin{array}{c}\text { Risk of the reflectory- } \\
\text { olfactory effects }\end{array}$ & 0.001 & 0.1 & 0.01 \\
\hline Non-carcinogenic risk & 0.017 & 0.05 & 0.34 \\
\hline Carcinogenic risks & 0.000 & 0.00001 & 0.00 \\
\hline & Integrated indicator & & 0.35 \\
\hline
\end{tabular}

The ratio of risk of the reflectory-olfactory effects to the allowable value amounted to 0.01 , and the ratio of the total non-carcinogenic risk to the allowable level was 0.34 . Here, the integrated indicator was equal to 0.35 , which did not exceed the standard level $(\mathrm{IR} \leq 1)$. 


\section{Conclusion}

Human activity is transforming Earth's natural systems in ways that are profound, pervasive and accelerating. This transformation is generating a suite of health impacts that remain, in many instances, poorly characterized. However, ample evidence exists that nearly every dimension of human health is being affected, and it is likely that the disease burden associated with these aggregate ecosystem alterations is large and growing. We propose a more systematic and comprehensive approach to understanding the health impacts of ecosystem alteration to better inform decision making in the land-use planning, environmental conservation, and public health policy realms.

A paradigm shift is required for us to embrace concepts of sustainability and explore the consequences of decision making that affects human and ecosystem integrity. Harmonizing environmental, economic, and social opportunities for the benefit of present and future generations creates an opportunity to understand the influence of inherent chemical, geophysical, and social attributes and stressors on human health and ecological integrity. It is further recognized that whereas underestimating the impact of certain stressors and related exposures may result in contamination or adverse health effects, overestimating the potential hazards could create an economic burden on communities.

Since here when the value $\mathrm{RfD} / \mathrm{C}$ was deduced from the experimental rather than epidemiological data, which allows quite reliable evaluation concerning human NOAEL and LOAEL, there remained some uncertainties connected rather with the differences between populations than with the differences between individuals, since these data, as a rule, refers to the observed professionals which can be distinguished by a number of biological and social characteristics different from the population, as a whole, for which the safe exposure level was estimated.

The assessment of ecological and hygiene risks posing sustainable functioning of the ecosystem of the Yenisei River has been developed in accordance with the devised methodology. It allows characterizing the quality of the water as moderately polluted, which corresponds to a good ecological potential and stability.

A conclusion was made that the studied transacts of the River Yenisei had a good environmental health with a moderate level of ecological risks. The total index of risk for the water, considering the reference doses, amounts to 0.16 for the water, and to 0.47 for the flesh of commercial fish. The total index of risk for the population consuming freshwater and fish from the Yenisei River amounts to $I R=0.63$. The obtained value of the index is, in general, of no danger for the population health.

\section{Reference}

Baird, D.J., Rubach, M.N. and Van den Brink, P.J. (2008). Trait-Based Ecological Risk Assessment (TERA): The New Frontier. Integrated Environmental Assessment and Management, 4: 2-8.

Bogardi, I., Bardossy, A., Mays, M.D. and Duckstein, E. (1996). Risk assessment and fuzzy logic as related to environmental science. Soil Science Society of America, pp.81-97.

Bondareva, L. (2010). New data about the radioecological state of the Yenisei River. The Mendeleev's Russian Journal of Chemistry, 3: 153-161. 
Bondareva, L. and Schultz, M.K. (2015). Investigation of the tritium content in surface water, bottom sediments (zoobenthos), macrophytes, and fish in the mid-stream region of the Yenisei River (Siberia, Russia). Environ. Sci. Pollut. Res. Int., 22(22): 18127-18136.

Bondareva, L. and Zhizhaev, A. (2010). Radiation-Chemical Situation of the waters of the middle reach of the River Yenisei (Russian Federation). Journal of Environmental Science and Engineering, 9: 1-11.

Bondareva, L., Fedorova, N. and Rakitskii, V. (2017). Mathematical calculation of the mass transport in water flow of the River Yenisei in the impact zone of the mining and chemical combine. Environmental Pollution and Protection, 1: 6-14.

Bondareva, L., Zeer, G., Gerasimov, V. and Zhizaev A. (2013). Technogenic pollution and its migration in the water flow of the Yenisei River. River Systems, 3-4: 149-156.

Deckere, E., Cooman, M., Florus, M.P. and Devroede-van der, L. (2000). Characterizing the sediments of Flemish Watercourses: a Manual produced by TRIAD - Brüssel: AMINALDepartment Water, $110 \mathrm{p}$.

Dmitriev, V.G. (2014). Assessment of environmental risk. Analytical review of publications. Arctic and North, 14: 126-147.

EPA/630/R-00/001 (2000). Supplementary Guidance for Conducting Health Risk Assessment of Chemical Mixtures. Risk Assessment Forum U.S. Environmental Protection Agency. Washington, DC 20460, 209 p.

GAO, 2001. Chemical Risk Assessment. Selected Federal Agencies' Procedures, Assumptions and Policies. United States General Accounting Office: Report to Congressional Requesters. GAO-01-810. 234 p.

IRIS/HEAST. United States Environmental Protection Agency. https://www.epa.gov/iris

Ivanov, V.V. (1994). Ecological geochemistry of elements, vol. 3. pp.456., Moscow: Nedra.

Ives, A.R. and Carpenter, S.R. (2007). Stability and Diversity of Ecosystems. Science, 5834: 5862.

Jardine, C., Hrudey, S., Shortreed, J., Craig, L., Krewski, D., Furgal, C. and McColl, S. (2003). Risk management frameworks for human health and environmental risks. J. Toxicol. Environ. Health B. Crit. Rev., 6:569-720.

Lukyanenko, V.I. (1983). General Ichthyotoxicology. 320 pp. (in Russian). Moscow: Textile and Food Industry.

Majaneva, M., Autio, R., Huttunen, M., Kuosa, H. and Kuparinen, J. (2009). Phytoplankton monitoring: the effect of sampling methods used during different stratification and bloom conditions in the Baltic Sea. Boreal Env. Res., 14: 313-322.

Malkhazova, S.M. and Koroleva, E.G. (2011). Environment and Human Health: A Training Manual. Geography Faculty of Moscow State University, Moscow. pp.180.

Moore, J.V. and Ramamurthy, S. (1987). Heavy metals in natural waters. Moscow: Mir. 288 p.

Murphy, B.R. and Willis, D.W. (1996). Fisheries Techniques. 2nd Edition, American Fisheries Society, Bethesda.

Onischenko, G.G., Zaitseva, N.V. and May, I.V. (2014). Analysis of the health risk in the strategy of state social and economic development. Perm: Publishing house of Perm. nat. Issled. polytechnical. University. 738 p.

Onishchenko, G.G. (2003). Sustainable provision of drinking water to the population of Russia to prevent the incidence of infectious and non-infectious diseases. Hygiene and Sanitary, 2: 36.

OSPAR (2016). CEMP Guidelines: Phytoplankton monitoring (OSPAR Agreement 2016-06). Available online at http://www.ospar.org/work-areas/cross-cutting-issues/cemp, choose document "CEMP Eutrophication Monitoring Guidelines: Phytoplankton Species 
Composition (Agreement 2016-06)". OSPAR Commission, 11 pp. [Accessed on 26.9.2016] Portt, C.B., Coker, G.A., Ming, D.L. and Randall, R.G. (2006). AR-1240. A review of fish sampling methods commonly used in Canadian freshwater habitats. Canadian Technical Report of Fisheries and Aquatic Sciences, 2604: 58.

Potapov, A.I. and Yastrebov, G.G. (2000). Socio-hygienic monitoring - practice of application and scientific maintenance of a problem, Part 1:21-27. Moscow: Science.

Pravdin, I.F. (1966). Guide to the study of fish. 376 pp. (in Rissian). Moscow: Food Industry.

Rivier, I.K. and Bakanov A.I. (1984). Feeding base of fish. Biological resources of reservoirs. pp.100-131. Moscow: Science.

Shakirova, Yu.A. (2006). The role of the water factor in the formation of public health. Ecological and hydrological problems of studying and using water resources: Collection of scientific works. pp.458-460. Kazan: Kazan State University.

Stepanova, N.Y. (2008). Factors and criteria for assessing the environmental risk for the sustainable functioning of the Kuibyshev reservoir. Diss. on the competition Dr. Biol. Sciences. Kazan State University (in Russian).

Vykhristyuk, L.A. (1989). Biogenic load and hydrochemical regime. pp.31-49. Moscow: Science. WHO (2004). Guidelines for Drinking-water Quality, 2004. $3^{\text {rd }}$ Edition, Volume 1. WORLD HEALTH ORGANIZATION Library Cataloguing-in-Publication Data. ISBN 92-41546387.

Zemlyanova, M.A. (2002). Scientific substantiation of the structural and functional model of ensuring hygienic safety of the population in conditions of natural and man-caused impact of chemical factors. Diss. on the competition Dr. Biol. Sciences. Moscow State university.346 p. (in Russian). 